Original Research Article

\title{
Management of soft tissue injury in the open tibia fractures
}

\author{
Patel P. ${ }^{1}$, Gandhi V.P. ${ }^{2}$ \\ ${ }^{1}$ Dr. Pragnesh Patel, ${ }^{2}$ Dr. Vimal P. Gandhi, both authors are Assistant Professor and affiliated with Department of \\ Orthopedics, GMERS Medical College, Dharpur, Patan, Gujarat, India.
}

Corresponding Author: Dr. Vimal P Gandhi, GMERS Medical College, Dharpur, Patan, Gujarat, India. E-mail: researchguide86@gmail.com

\begin{abstract}
Background and Aim: Development of newer techniques and concepts of limb salvaging such as debridement, vascular reconstruction, soft tissue reconstruction and the use of microsurgical techniques has revolutionised the treatment of open fractures. Although, not all problems that confronted trauma surgeons in the past have been completely resolved; modern methods of open fracture management, skeletal fixation and soft tissue and bone reconstructions have dramatically improved the limb salvage. Materials and Methods: The present study was a prospective study of type III B open tibia fractures treated by skeletal stabilisation and soft tissue coverage in 60 patients. Soft tissue coverage was obtained by means of SSG in 16 patients, by fasciocutananeous flap in 26 patients and by muscle flap with SSG in 18 patients. Results: In this study sound bony union was obtained in 54 out of 60 cases with soft tissue coverage in 46 cases on primary basis and in 14 patients after secondary procedures. In cases with fasciocutaneous flap who had undergone external fixator had non-union. In the present study it was observed excellent results in 49 patients, good in 10 patients and poor in 1patient based on the scoring system in which parameters like soft tissue coverage, bone union/non-union. Conclusion: Timely meticulous wound management and early soft tissue cover leads to early sound bone healing and early restoration of the function of the limb. In type III open fractures internal fixation can be contemplated when presentation is early with minimal contamination; comminution and adequate soft tissue coverage can be obtained on acute basis.
\end{abstract}

Keywords: Tibia, Type IIIB fractures, Debridement, flaps

\section{Introduction}

The tibia is a triangular-shaped bone in cross section in its diaphysis. Proximally, the tibial tubercle is found anterolaterally about $3 \mathrm{~cm}$ below the articular surface. This site serves as a point of attachment for the patellar tendon [1]. Directly posterior to the patellar tendon is a richly vascularized fat pad. The diaphysis becomes thinner distally, which means that it is particularly at risk from twisting injuries. Incidence of open tibia fracture is $23.5 \%$ [2].

The main soft tissue problems associated with open tibial fractures are management of the open wound, the muscle damage associated with the fracture, neurovascular injury, and the type of surgery that is required to close the wound once the fracture has been stabilized. In an open tibial fracture, the most important component of the initial surgery is the debridement or

Manuscript Received: $18^{\text {th }}$ September 2019

Reviewed: $28^{\text {th }}$ September 2019

Author Corrected: $5^{\text {th }}$ October 2019

Accepted for Publication: $10^{\text {th }}$ October 2019 wound toilet that must be carried out to remove all devitalized and contaminated tissues. If this procedure is performed inadequately, the incidence of infection rises dramatically, and the patient may have to undergo much expensive, time-consuming surgery to achieve soft tissue healing and bone union $[3,4]$.

All patients with open tibial fractures will be treated with an appropriate antibiotic regimen both pre- and postoperatively, but the administration of antibiotics should never substitute for an adequate surgical debridement. Some surgeons recommend primary flap cover after debridement and stabilization of open fractures. Gopal et al analyzed 80 open tibial diaphyseal fractures that were treated with early stabilization and flap cover [5]. Their overall limb salvage rate was $95 \%$ and the rate of flap failure was $3.5 \%$. They emphasized that internal fixation was preferable to external fixation and that their results were much better in those patients that had flap cover as part of the primary operative 


\section{Original Research Article}

procedure $[5,6]$. This may be a useful technique if it is logistically feasible and if the surgeon can guarantee that there is no residual contamination after debridement. In this study 30 cases of type IIIB open tibia fractures have been studied where the results were obtained after fracture fixation with different techniques and soft tissue coverage. To evaluate the clinical outcome of soft tissue coverage in open tibia fractures.

\section{Material and Method}

\section{Type of study}

A prospective study of type III B open tibia fractures treated by skeletal stabilisation and soft tissue coverage in 60 patients. Total of 60 patients were included in the study. All the patients were admitted in the medical hospital, attached to medical college.

The ethical committee of the institute were informed and the ethical clearance certificate was obtained from them, prior to the conduction of the study. All the included patients were informed about the study and the written informed consent was obtained from each of them.

\section{Study design}

The full examination of the injured limb was done and the fracture was graded as per the Gustilos grading of the fracture. Debridement of the wound was done in the next department. As per the radiological examination, the evaluation of the fracture was done. Management of the fracture was based on the condition of the patient and type of fracture.

\section{Inclusion criteria}

Age less than 60 years, presence of tibial fracture of IIIB type of Gustilo's classification, presence of open fracture.

\section{Exclusion criteria}

Age above 60 years, loss of soft tissues, patients with diagnosis of osteomyelitis or any tumour, presence of diabetes mellitus, perivascular diseases, artherosclerosis and serious medical illness.

Type of coverage included split thickness skin grafting; fasciocutaneous flap, Muscle flap with SSG. POST OP Monitoring Post operatively antibiotics were instituted as per wound culture and sensitivity.

If external fixator was used then the patient was examined for pin tract infection, pin loosening, loss of fixation on $1^{\text {st }}, 3^{\text {rd }}, 5^{\text {th }}$ day, 1 week, 2 weeks.

If intramedullary fixation was used then patient was examined for infection, loosening and the loss of fixation $1^{\text {st }}, 3^{\text {rd }}, 5^{\text {th }}$ day, 1 week, 2 weeks. In case of SSG wound was examined on 1 st and 5 th day, 1 week and at 2 weeks. In case of flap on day $1^{\text {st }}, 3^{\text {rd }}$ and $5^{\text {th }}$ day, 1 week and at 2 weeks.

Patients were started on knee and ankle exercises as per the stability of fixation and the soft tissue cover. Patients were discharged at around $14^{\text {th }}$ to $20^{\text {th }}$ postoperative day.

\section{Results}

In the present study 60 cases of type IIIB open tibia fractures were treated with fixation and soft tissue coverage with SSG or fascicutaneous flap or muscle flap with SSG. In the present study it was analyzed that maximum number of cases belong to age group of 31-40 years and least number of cases were found in age group below 10 years. There were 52 males and 8 females.

Table-1: Age distribution among the study population.

\begin{tabular}{|c|c|}
\hline Age in years & No. of cases \\
\hline $0-10$ & 2 \\
\hline $11-20$ & 8 \\
\hline $21-30$ & 13 \\
\hline $31-40$ & 23 \\
\hline $41-50$ & 8 \\
\hline $51-60$ & 6 \\
\hline
\end{tabular}

In the present study, spiral type of fracture was found in 20 cases, oblique type of fracture was found in 30 cases and 10 cases had communited fracture. Based upon the AO/ASIF soft tissue injury classification; 52 cases had increased severity of injury whereas 6 cases had special injury. 
Original Research Article

Table-2: Type of fracture.

\begin{tabular}{|c|c|}
\hline Type of fracture & No. of patients \\
\hline Oblique & 30 \\
\hline Spiral & 20 \\
\hline Communited & 10 \\
\hline
\end{tabular}

Based on the type of injury, external fixation was done in 32 cases, internal fixation was done in 22 cases; whereas in 4 cases no fixation was done. For the associated soft tissue injury, the soft tissue coverage was done using SSG in 16 cases, muscle and SSG combination flap was used in 18 cases where in 26 cases there was use of fasciocutaneous flap.

Table-3: Type of soft tissue coverage.

\begin{tabular}{|c|c|}
\hline Type of coverage & No. of cases \\
\hline SSG & 16 \\
\hline Muscle + SSG & 18 \\
\hline Fasciocutaneous flap & 26 \\
\hline
\end{tabular}

In the present study, the healing of soft tissue was obtained in 46 patients in the primary healing and in 14 cases it was obtained on secondary healing stage. Owing to the bone healing the overall union was observed in 54 cases, 4 patients had non-union and in 2 patients there was amputation. In the present study; 49 patients had excellent outcome. 10 patients had good outcome whereas poor outcome was seen in 1 patient only.

Table-4: Overall result evaluated

\begin{tabular}{|c|c|}
\hline Grade & No. of patients \\
\hline Excellent & 49 \\
\hline Good & 10 \\
\hline Poor & 1 \\
\hline
\end{tabular}

\section{Discussion}

The annual incidence of open fractures of long bones has been estimated to be 11.5 per 100000 persons [7] with $40 \%$ occurring in the lower limb commonly at the tibia diaphysis [8]. Open fractures in the leg tend to be more severe compared with those in the arm because of the degree of soft-tissue damage and the frequency of associated musculoskeletal injuries.

Type IIIB open fracture injury constitute most severe open injury with an incidence of infection being $25 \%$ without fixation and it could be $50 \%$ or higher following internal fixation. Wound closure and soft tissue management takes the priority in the open fractures over the bone healing. All the studies done so far have emphasized / centered around soft tissue coverage for the subsequent early bone healing. In the present study soft tissue coverage was done in 60 patients of type IIIB open tibia fractures [9]. 30 patients sustained oblique fractures, 20 patients had spiral fractures and 10 patients had comminuted fractures in the present study. Schandelmaier et al reported $47 \%$ spiral / comminuted fractures and 53\% oblique fractures in their study $[10,11]$. In their study Court-Brown et al reported $46 \%$ spiral/ comminuted fractures $54 \%$ oblique fractures. Keating et al reported $46.4 \%$ spiral/ comminuted fractures and $53.65 \%$ oblique fractures [12].

The major concern for the immediate closure in earlier years was increased risk of infection on the premise that the offending organism leading to infection was introduced at the site of accident [13]. However, there is ample evidence that infection is generally a result of hospital acquired colonization of the wound, rather than the primary contamination at the time of injury. There is no correlation between the organisms of primary wound contamination and post-operative bacterial culture.

Many surgeons are still inclined to fix the fractures and cover the wound emergently in the case of some Gustilo IIIB open fractures in which the soft tissue is not obviously damaged, and this strategy is usually 


\section{Original Research Article}

beneficial. However, in the case of serious Gustilo IIIB fractures with large bone defects and serious soft tissue injury, the ideal treatment strategy is still unclear. Many surgeons are of the opinion that it is risky to perform emergency internal fixation and flap closure of the wound, so staged surgery seems like a viable option for reducing complications in such cases.

However, along with the placement of external fixators, it is also important to use small implants to fix fractures to reduce complications in later stages $[14,15,16]$. In addition, it is very important to prevent infections in seriously contaminated wounds when the preoperative time is long. It is very difficult to remove all the polluted tissue and control for potential infections in the case of these wounds.

Therefore, closing the wound emergently may not be the best option; instead, vacuum-closed drainage, and wound irrigation have been shown to have good results in the clinic.

In the present study most of the primary wound contamination was gram positive and post-operative wound culture showed gram negative organisms. Hence leaving the wound open can lead to colonization of difficult flora resulting in deep infection. Hence, primary closure in open injury should be the goal of the treatment.

To assess the outcome, the scoring criteria was prepared based upon the parameters mentioned in the table. Patients with primary soft tissue healing and bone union without any major complications were considered to have excellent result and were graded as ' $A$ '. Patients with primary soft tissue healing/secondary soft tissue healing and bone union with major complications like deep infection were considered to have good result and designated as ' $\mathrm{B}$ '. Patients with primary soft tissue healing/ secondary soft tissue healing and non- union with major complications requiring amputation / repeated surgeries were considered to have poor results and were designated as grade ' $\mathrm{C}$ '. Primary wound closure is a safe option in properly selected cases. Prospective multi-centre studies are needed to further evaluate the safety and efficacy of this treatment alternative.

\section{Conclusion}

All patients were preoperatively assessed both clinically and radiologically and operated with skeletal stabilisation with internal or external fixation or splint and soft tissue coverage with SSG, fasciocutaneous flap, muscle flap and SSG. Follow up was done clinically and radiologically at $4,8,12,16,20$ weeks or till soft tissue healing and bone healing was achieved. In the present study it was observed excellent results in 23 patients $(76.66 \%)$, good in 5 patients $(16.66 \%)$ and poor in 2 patients $(6.66 \%)$.

\section{What the study adds to the existing knowledge?}

It is important to correctly assess the patients' condition and accordingly select the approach to cover the wound. When the patients' general condition and wound infection are controlled, different kinds of skin flaps and myocutaneous flaps should be used, as appropriate, to repair the wounds and close them in the second stage.

If the wound is healed in the later phase, internal fixation or other comprehensive treatments for late complications should be performed as required.

\section{Author's contribution}

Dr. Pragnesh Patel: Formulated the aims and objectives with study design and helped in data collection from medical record department.

Dr. Vimal P. Gandhi: Preparation of the manuscript and data analysis.

Conflict of interest: None declared.

Funding: Nil, Permission from IRB: Yes

\section{References}

1. Thompson JE. Anatomical methods of approach in operations on the long bones of the extremities. Ann Surg. 1918;68 (3):309-329.doi:10.1097/00000658-1918 09000-00012.

2. Guelcher SA, Dumas JE, Prieto EM, Zienkiewicz K, inventors; Vanderbilt University, assignee. Injectable allograft pur composite carrying rhBMP2. United States patent application US 13/280,299. 2015 Oct 8.

3. Key JA. The use of sulfanilamide and sulfathiazole in orthopedic surgery: chairman's address. J Am Med Assoc. 1941;117(6):409-412. doi: 10.1007/s11999-0090797-7.

4. Poletti FL, Macmull S, Mushtaq N, Mobasheri R. Current concepts and principles in open tibial fracturesPart II Management and controversies. MOJ Orthop Rheumatol.2017;8(2): 00305.doi:10.15406/mojor. 2017. 08.00305 . 


\section{Original Research Article}

5. Liptak JM, Dernell WS, Ehrhart N, Lafferty MH, Monteith GJ, Withrow SJ. Cortical allograft and endoprosthesis for limb-sparing surgery in dogs with distal radial osteosarcoma: a prospective clinical comparison of two different limb-sparing techniques. Vet Surg.2006;35(6):518-533.doi:10.1111/j.1532-950X. 2006.00185.x

6. Clancey GJ, Hansen ST Jr. Open fractures of the tibia: a review of one hundred and two cases. J Bone Joint Surg Am. 1978;60(1):118-122.

7. Cross WW 3rd, Swiontkowski MF. Treatment principles in the management of open fractures. Indian $\mathrm{J}$ Orthop. 2008;42(4):377-386. doi: 10.4103/0019-5413. 43373.

8. Clawson Dk. Claw Toes Following Tibial Fracture. Clin Orthop Relat Res. 1974;(103):47-48. doi: 10.1097 /00003086-197409000-00029

9. Court-Brown CM, Rimmer S, Prakash U, McQueen MM. The epidemiology of open long bone fractures. Injury.1998;29(7):529-534.doi:10.1016/s0020-1383(98) 00125-9.

10. Schandelmaier P, Krettek C, Rudolf J, Kohl A, Katz $\mathrm{BE}$, Tscherne H. Superior results of tibial rodding versus external fixation in grade $3 \mathrm{~B}$ fractures. Clin Orthop Relat Res. 1997;(342):164-172.
11. Musahl V, Tarkin I, Kobbe P, Tzioupis C, Siska PA, Pape HC. New trends and techniques in open reduction and internal fixation of fractures of the tibial plateau. $\mathrm{J}$ Bone Joint Surg Br. 2009;91(4):426-433. doi: 10.1302/ 0301-620X.91B4.20966.

12. Court-Brown CM, McBirnie J. The epidemiology of tibial fractures.J Bone JointSurg Br.1995;77(3):417-421

13. Ingram P, Lavery I. Peripheral intravenous therapy: key risks and implications for practice. Nurs Stand. 2005;19 (46): 55-64. doi: 10.7748/ns2007.09.22.1.44. $\mathrm{c} 4613$

14. Kim JW, Oh CW, Jung WJ, Kim JS. Minimally invasive plate osteosynthesis for open fractures of the proximal tibia. Clin Orthop Surg. 2012;4(4):313-320. doi: 10.4055/cios.2012.4.4.313. Epub 2012 Nov 16.

15. Tong D, Ji F, Zhang H, Ding W, Wang Y, Cheng P, et al. Two-stage procedure protocol for minimally invasive plate osteosynthesis technique in the treatment of the complex pilon fracture. Int Orthop. 2012;36 (4): 833-837. doi: 10.1007/s00264-011-1434-0. Epub 2011 Dec 20.

16. Ma CH, Yu SW, Tu YK, Yen CY, Yeh JJ, Wu CH. Staged external and internal locked plating for open distal tibial fractures. Acta Orthop. 2010;81(3):382-386. doi: $10.3109 / 17453674.2010 .487244$.

\section{How to cite this article?}

Patel P, Gandhi V.P. Management of soft tissue injury in the open tibia fractures. Surgical Update: Int $J$ surg Orthopedics.2019;5(4):288-292.doi:10.17511/ijoso.2019.i04.09 